\title{
CANDIDATE BALLOT INFORMATION AND ELECTION OUTCOMES: THE CZECH CASE
}

\author{
Štěpán Jurajda \\ Daniel Münich
}

Charles University

Centerfor Economic Research and Graduate Education

Academy of Sciences of the Czech Republic

Ec onomics Institute

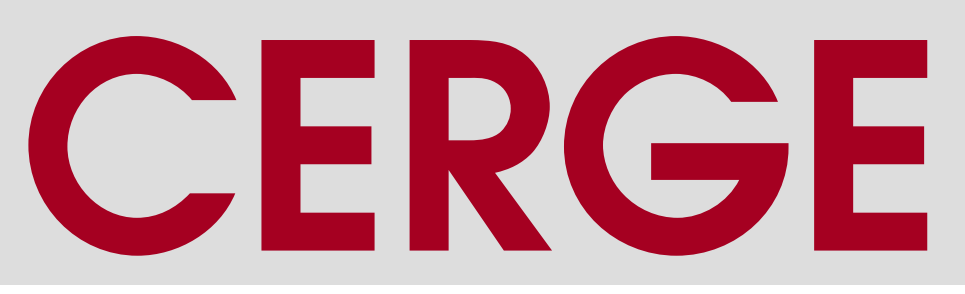




\section{Working Paper Series $\quad 500$ (ISSN 1211-3298)}

\section{Candidate Ballot Information and Election Outcomes: The Czech Case}

Štěpán Jurajda

Daniel Münich

CERGE-EI

Prague, January 2014 
ISBN 978-80-7343-304-8 (Univerzita Karlova. Centrum pro ekonomický výzkum a doktorské studium)

ISBN 978-80-7344-297-2 (Akademie věd České republiky. Národohospodářský ústav) 


\title{
Candidate Ballot Information and Election Outcomes: The Czech Case
}

\author{
Štěpán Jurajda and Daniel Münich \\ CERGE-EI
}

January 10, 2014

\begin{abstract}
We measure the importance of candidate characteristics listed on ballots for a candidate's position on a slate, for preferential votes received by a candidate, and, ultimately, for getting elected. We focus on the effects of gender, various types of academic titles, and also several novel properties of candidates' names. Using data on over 200 thousand candidates competing in recent Czech municipal board and regional legislature elections, and conditioning on slate fixed effects, we find ballot cues to play a stronger role in small municipalities than in large cities and regions, despite the general agreement on higher candidate salience in small municipalities. We also quantify the election advantage of a slate being randomly listed first on a ballot.
\end{abstract}

\begin{abstract}
V tomto článku kvantifikujeme význam charakteristik kandidátů uvedených na volebních lístcích ve volbách do zastupitelstev obcí a krajů v ČR pro pořadí na kandidátních listinách, pro obdržené preferenční hlasy a pro konečné volební výsledky. Měříme vliv pohlaví kandidátů, jejich různých akademických titulů a také několika vlastností jejich jmen. Naše analýza je založena na srovnání kandidátů uvnitř dané kandidátní listiny, ne na srovnání mezi kandidátními listinami. Dále měříme vliv náhodně vylosovaného pořadí kandidátních listin na volební výsledky.
\end{abstract}

JEL Codes: D72, D83

Keywords: Low-Information Elections, Ballot Order Effects, Name Properties

Acknowledgements CERGE-EI is a joint workplace of the Center for Economic Research and Graduate Education, Charles University, and the Economics Institute of the Academy of Sciences of the Czech Republic. Both authors are Research Affiliates at CEPR, London; S. Jurajda is also Research Fellow at IZA, Bonn. The help of Eva Jakubcová and Barbora Serbusová of the Czech Statistical Office in acquiring the data used in this paper is gratefully acknowledged, as is research assistance provided by Jekaterina Kuliomina. This research has been supported by the Karel Janeček Foundation.

Address CERGE-EI, Charles University Prague and Academy of Sciences of the Czech Republic, Politickych veznu 7, Prague 11121, Czech Republic. E-mail: stepan.jurajda@cerge-ei.cz, daniel.munich@cerge-ei.cz 


\section{Introduction}

Information is central to electoral choices. When voters cast ballots, they should primarily reflect information available to them about the candidates' qualifications for office and policy views. They may also be influenced by election advertising. However, when voters have little information about, or interest in, a candidate or when they are presented with large numbers of candidates or simply when fatigued, they may rely on simple heuristics and cues and be influenced in their vote by the limited information that is provided on the ballot they hold in their hands in the voting booth, rather than on a comprehensive assessment of candidates' quality and programs.

The literature on voting behavior now recognizes that in elections that are low in salience, i.e., in the degree of available information on candidate quality, ballot cues may affect election outcomes. Brockington (2003) summarizes the theory of low-information election behavior, which fits into the general research on low-information decision making (e.g., Kahneman, 1973). Three levels of information available to voters are considered: (i) primary information on candidates' qualifications or policy views collected by voters before arriving at the polling place, (ii) candidate characteristics potentially correlated with their qualifications and standpoints, which are available on the ballot, such as gender, education, or ethnicity, and (iii) cues, which should not be informative about the candidate's quality, but which may make voting decisions easier, such as the candidate order on the ballot when it is randomized.

There is now considerable empirical evidence suggesting that candidate characteristics provided on ballots as well as their order on the ballots are relevant to election outcomes. Evidence that candidates receive an advantage from their position on a ballot comes from countries where the candidate order is random. However, most of this work is based on a single election in one country, which makes it difficult to compare the importance of ballot cues across election settings differing in salience, i.e., in the degree of available primary information. Specifically, the importance of information of types (ii) and (iii) for voters' 
choices is likely to be higher when there is little primary information available on candidates (as in US city board elections; see, e.g., Matson and Fine, 2006) or when voting is compulsory, which increases the share of uninterested uninformed voters (as in Australia; see Kelley and McAllister, 1984). The cost of primary (type (i)) information per candidate is also likely to depend on the extent of media coverage and on the number of candidates.

In this paper we extend the low-information election literature by exploring the potential effects of candidates' names as cues, including the importance of their names' linguistic properties, ethnic attributes, and popularity. We also study the election behavior effects of gender, academic titles and graduate degrees. Further, we test for 'residual' alphabetical order effects in elections where parties determine the slate order, i.e., when candidates are not formally ordered based on the alphabet, and we appear to be the first to quantify the position advantage of the random slate order within a ballot. ${ }^{1}$

We do so using data on over two hundred thousand candidates participating in recent Czech municipal elections and over eight thousand candidates running in recent Czech regional elections. Section 3 describes these elections, which have been characterized as differing in salience and voter interest. Specifically, voters tend to be familiar with candidates for the six thousand municipal boards in small towns and villages, whilst their knowledge of candidates in large cities or in the thirteen regional elections is more limited.

We recognize that candidate quality and voter political preferences may differ across slates in ways that are correlated with ballot cues and base our candidate cue analysis on withinslate comparisons. For both elections, we thus do not analyze which slates are ultimately more successful, but ask whether ballot cues have predictive power for preferential votes cast by voters conditional on the overall attractiveness of a given slate. We also study how the slate position of candidates, set by parties, is related to candidate ballot characteristics and whether ballot cues affect election chances conditional on the slate order.

\footnotetext{
${ }^{1} \mathrm{~A}$ slate is a group of candidates running on a common platform in multi-seat elections.
} 


\section{Related Literature}

Our analysis is related to three strands of the voting behavior literature, which we now briefly introduce. First, the distinct under-representation of women among legislators has motivated work which asks about the slate position of women in elections where the order is determined by parties, and about the electoral value of gender, i.e., about voter gender preferences when comparing two otherwise comparable candidates of different gender. For example, Esteve-Volart and Bagues (2012) study party nomination strategies in Spain and find that women tend to be nominated in poorer (lower) positions on the ballot, despite attracting more votes than comparably positioned men.

Second, a small set of studies asks about the ballot value of holding an academic title, conditional on how candidates are ordered. Faas and Schoen (2006) and Schneider and Tepe (2011) suggest there is positive election value to the Ph.D. title in German federal elections while Kelley and McAllister (1984) find no relationship between holding a professor or doctor title in British general (parliamentary) elections.

Third, there is a growing body of work studying ballot-order effects. ${ }^{2}$ Meredith and Salant (2013) summarize and extend the literature that measures the advantage of being listed first on ballots in countries such as the US, Spain, or Australia where candidate order is randomized (typically using alphabetical randomization), such that the order is not informative about the candidates' quality. In their analysis of California city council and school board elections, candidates listed first typically win office about five percentage points more often thanks to the order effect. Similar findings have been obtained for elections where candidates are simply listed in alphabetical order (e.g., Kelley and McAllister, 1984). ${ }^{3}$

\footnotetext{
${ }^{2}$ This work is part of the order-effects literature, which covers various types of contests including classical music competitions (van Ours and Ginsburgh, 2003) or school admissions (Jurajda and Münich, 2010). More generally, the literature on voting behavior asks how the design of ballots and voting technology may affect electoral and policy outcomes (e.g., Fujiwara, 2013).

${ }^{3}$ There is little work on order effects in elections where parties determine the ordering of candidates within
} 
In this paper, we estimate the within-slate electoral (preferential vote) value of academic titles as well as that of tertiary education degrees (which appears to be rare in this literature) and of gender in two Czech elections. We also ask whether alphabetical sorting plays a role for candidate position on a slate in an election where candidate order is determined by parties. This question is different from the ballot order effects estimated in the existing literature, where ballot order is random (or purely alphabetical). We ask whether the omnipresent use of alphabetically sorted lists may leave a residual trace once parties (re-)sort candidates 'by hand' based on candidate quality. Voters may also (sub-consciously) prefer candidates whose names are sorted high in the alphabet. ${ }^{4}$ Next, we ask about two novel order effects: First, we ask about the potential advantage to a slate being randomly chosen as the first slate on a ballot (as opposed to the first candidate within a ballot). Second, we inquire about the effect of a male candidate being positioned within a slate immediately above or below a female candidate. If, for example, voters have on average negative views of female candidates' ability, they may ascribe information value to a male candidate who is sorted below (close to) a female candidate.

Furthermore, we explore the potential effects of other-than-alphabetical properties of candidate names. There are a few studies of the effects of candidate ethnicity in low-information elections (e.g., Matson and Fine, 2006). ${ }^{5}$ We perform a similar analysis in the Czech context by focusing on Roma names, Roma being the largest minority in the country. ${ }^{6}$

We also study novel aspects of names as cues such as the general popularity of first names,

slates, in large part because in this case the order contains information about the (party-perceived) quality of the candidates. Faas and Schoen (2006) are an exception based on a quasi-experimental design.

${ }^{4}$ For example, The Economist (2001) points out the high fraction of U.S. presidents and U.K. prime ministers with last names sorted high in the alphabet.

${ }^{5}$ Similarly, economists have explored the labor-market effects of racial attributes of first names (Bertrand and Mullainathan, 2004; Fryer and Levitt, 2004; Aura and Hess, 2010).

${ }^{6}$ The European Commission has identified the standing of the Roma minority as one of its key policy challenges; see, e.g. http://ec.europa.eu/roma. 
as well as several linguistic properties suggested in consumer research studying the effects of brand names. Brand name research borders on linguistic psychology and onomastics (the part of linguistics that studies names); it highlights the value of semantic and connotative values of brand names in marketing campaigns. For example, in one of the most extensive studies conducted to-date, Lowrey et al. (2003) investigate the effect on brand-name memory of several linguistic characteristics hand-coded for 500 brand names and find that initial plosives (hard initial consonants such as $k$ and $p$ ) are shown to affect brand memorability.

There is only one paper we are aware of that explores the potential effects of linguistic name properties in elections: Smith (2007) follows the arguments of phonetic symbolism ${ }^{7}$ and ranks surnames of candidates in US congressional elections according to their rhythmic and phonetic features to generate statistically significant predictors of US elections. ${ }^{8}$ We are not aware of any low-information electoral studies that would ask about the value of having a popular first name or that would apply the suggestions made in recent consumer research on brand names to the study of electoral competitions.

We also present one of the few available comparisons of the importance of ballot information of types (ii) and (iii) for election choices and outcomes across otherwise comparable election settings ${ }^{9}$ characterized by a different degree of salience and voter interest. Specif-

\footnotetext{
${ }^{7}$ Phonetic (sound) symbolism refers to the ability of phonemes (the fundamental building blocks of language) to convey information on their own (Yorkston and Menon, 2004). For example, Lowrey and Shrum (2007) suggest that participants in experiments least prefer fictitious brand names containg negative vowel sounds, i.e., sounds that generally have negative connotations in the English language. Similarly, Nelson and Simmons (2007) present evidence suggesting sub-conscious effects of name connotations.

${ }^{8}$ The analysis is based on assigning 'points' to the relevant several hundred candidate names for their phonetic properties such as rhythm, stress position, vowel stress depending on position in the name, terminal nasal position, etc. The assignment was originally developed in 1998 and over subsequent years it was applied to several US elections. Unfortunately, such assignments cannot be easily automated and so remain outside of the scope of our study, where we work with several hundreds of thousands of names.

${ }^{9}$ We study the effects of cues such as name properties or academic titles within one country, where they are likely to be consistently valued across different elections.
} 
ically, we employ data from the 2008 regional and 2010 municipal elections in the Czech Republic. There are about six thousand small municipalities in the country, where voters tend to be aware of the identity and quality of the village-board candidates from their municipality. There are about three hundred cities (with at least five thousand inhabitants), where city board composition and candidate quality is likely to be less salient to voters. Finally, there are only fourteen regions (with about one million of inhabitants each), which have only been established in 2010, where salience levels and voter interest are likely to be lowest. ${ }^{10}$

When one finds that cues of type (iii) are more relevant for election outcomes in one election setting compared to another, it is likely that this corresponds to cues being used more often by uninformed, potentially uninterested voters as short-cuts towards making decisions in low salience situations. However, for information of type (ii), it is not possible to fully disentangle what part of explanatory power is due to such ballot information being used as cues by uninterested voters, ${ }^{11}$ what part is due to the use of this information by voters to guess about a candidate's quality (since ballot information such as education or gender is likely to be correlated with candidates' true qualifications for office and policy views), and, finally, what part of the difference in predictive power across election settings corresponds to the potentially different correlation between voter-observed primary (type (i)) information on the quality of candidates and the candidates' ballot-listed characteristics.

Our empirical analysis of candidate characteristics focuses on within-slate comparisons. ${ }^{12}$ This is motivated by the fact that candidate quality is hard to observe, which makes it fundamentally difficult to disentangle the effects of gender, education, and other ballot observables

\footnotetext{
${ }^{10}$ Czech electoral studies (published in Czech) highlight the relatively low importance of and voter interest in regional elections (Šaradín, 2008; Havlík and Hoskovec 2009) and the typically intimate voters' knowledge of municipality-election candidates (Čmejrek, et al., 2010; Balík, 2009). The turnout in the last (2010) municipal elections was $48.5 \%$ while the turnout in the last (2012) regional elections was $37 \%$.

${ }^{11}$ As when voters prefer, for example, candidates similar to themselves (Cutler, 2002).

${ }^{12}$ For a similar approach, see Faas and Schoen (2006).
} 
from the unobservable quality of candidates. More specifically, identification of the effects of ballot-listed candidates' characteristics as cues in low-information elections (through channels (ii) and (iii)) is made difficult by the fact that candidates' characteristics observable on the ballot paper may be correlated with their characteristics observable to the voters, but not to us, and by the fact that candidates and parties (slate coalitions) know that the outcome of the elections is primarily affected by the choice of the slate, ${ }^{13}$ which makes it likely that they form slates in ways which enhance their election chances. On the one hand, one would expect observable candidate characteristics from the ballot to be positively correlated with the qualities that are unobservable to us (for example, one may expect candidates with higher education to actually have better managerial skills). On the other hand, slates that are registered by parties who know they stand a relatively low chance of being elected based on the political preferences of the electorate may try to improve their election chances by intentionally using candidates with high-value ballot-observable characteristics and cues. ${ }^{14} \mathrm{We}$ therefore conduct all of our candidate-cue comparisons within slates, taking as given both the hard-to-control-for local preferences for parties or slates and the endogenous process where candidates form slate coalitions reflecting strategic combinations of unobservable quality and observable characteristics with the purpose of attracting voters to their slates.

Our empirical analysis separately studies the determinants of one's position on a slate, the determinants of preferential votes received given one's position on a slate, and, ultimately, the determinants of getting elected on a city or regional council. In this regard, our work is similar to the analysis (published in Czech) of the 2010 Czech municipal elections by Bernard (2012), who merges the 2010 election data with information on prior municipal board membership and focuses on the importance of incumbency for election chances. He finds incumbency

\footnotetext{
${ }^{13}$ See the next two sections for a description of the Czech elections we study.

${ }^{14}$ Even if these candidates may be of low quality in terms of their less easily observable characteristics such as managerial skills, not being prone to corruption, having a real interest in municipality management, etc.
} 
to be the strongest predictor of election success. ${ }^{15}$ Unlike our work, Bernard's analysis does not focus on within-slate comparisons and does not consider the potential effects of candidate name properties, either ethnic or linguistic. He also does not differentiate among different types of academic titles and education degrees and does not ask about slate position advantages. Finally, unlike Bernard's, our analysis compares the importance of information cues across two types of elections.

In the next two sections, we introduce the Czech elections and the data we use. Section 5 presents the empirical analysis while the last section concludes.

\section{Czech Municipal and Regional Elections}

In the Czech Republic, there are three levels of government: central, regional, and local, corresponding to parliamentary, regional, and municipality elections. The proportional representation system is used in all three elections with a 5 percent entry threshold, but the mandate formulas are somewhat different. In this paper, we study the regional and local (municipal) elections.

Since 2000 the Czech Republic has been composed of 14 administrative regions (including the capital city of Prague), which have their regional legislature (councils) directly elected for four-year terms. ${ }^{16}$ A regional governor ('hejtman') is then elected by regional councils. Slates (candidate lists) can be registered in a given region by national-level political parties as well as by movements (easy-to-register local 'parties' formed with the purpose of participating in one of the regional elections) and ad hoc coalitions thereof. Voters choose a preferred slate

\footnotetext{
${ }^{15}$ The interpretation of incumbency effects, similar to the effects of some other major candidate characteristics, is affected by unobservable candidate qualifications. It may be that genuinely better candidates win elections repeatedly or that incumbency gives one an electoral advantage over similarly qualified candidates thanks to the incumbent's higher familiarity.

${ }^{16}$ The number of council members varies from 45 in regions with up to 600,000 inhabitants to 65 in regions with over 900,000 inhabitants.
} 
and cast up to four preferential votes for candidates within their preferred slate in order to affect the slate's order of candidates. Council seats are determined using a proportional rule based on the d'Hondt method. Candidates receiving over 10 percent of all preferential votes received by their slate are given precedence within their slate. Given that the typical (median) slate contains 50 candidates, it is difficult to receive over 10 percent of all preferential votes cast by slate.

In local (municipal) elections, members of approximately six thousand municipal councils are also elected directly and mayors are then elected by and responsible to their councils. Similar to regional elections, slates for municipality elections can be registered by political parties and/or movements, but also by independent candidates (including slates composed of a single independent candidate). Any combination of slate coalitions between established national-level political parties, ad-hoc movements, and unions of independent candidates is possible. The maximum number of candidates on each slate corresponds to the number of councillors. $^{17}$

Unlike the regional electoral system, the municipal one allows for panachage, i.e., splitting one's votes across party (slate) lines using preferential votes. Voters can vote for a slate and/or for individual candidates from any slate that has been submitted. Specifically, a voter can (but does not have to) mark one preferred slate, which is equivalent to marking all candidates on that slate in the case that no preferential votes are cast, and can also mark his preferred individual candidates from other slates using preferential votes. The total number of preferential votes one can cast is equal to the number of councillors minus one in the case that the voter marks a preferred slate and equals the council size if the voter does not mark any slate and only marks individual candidates. Council seats are then determined using a complicated proportional rule based on the d'Hondt method, in which the slate's share of votes and one's position within the slate have a strong explanatory power

\footnotetext{
${ }^{17}$ Council size is proportionate to the population of the municipality and ranges from 5 to 55.
} 
for winning council seats. ${ }^{18}$ Preferential votes move a candidate to the top of the slate when the candidate receives over 10 percent more preferential votes than the average candidate on a given slate. The effect of preferential votes on the outcome of municipal elections is thus qualitatively larger than for regional elections.

\section{Data and Key Variables}

We use administrative election data provided by the Czech Statistical Office, which is in charge of the central processing of elections at all levels (parliamentary, regional, and municipality) including election outcome (legislature/council seat) determination. We exclude from the analysis of both elections the capital city of Prague, which uses a different electoral system. ${ }^{19}$ The data we employ correspond to the information about each candidate made available to voters on ballots: the candidate's first name and surname, ${ }^{20}$ a self-reported academic title and education degree, and birth year (age).

The municipal-election data corresponds to elections held in October of 2010 when the overall turnout rate was $48.5 \%$. Excluding the few election districts governed by exceptional electoral systems (chiefly the capital city of Prague), a total of 209,979 candidates participated in the contest for about sixty thousand seats on 6,107 municipal councils. Nine tenths of the election districts had fewer than nine slates registered and the average number of slates per municipality was 4.5. Slate order on ballots was drawn randomly in each electoral district. About $21 \%$ of slates won no seats and about $5 \%$ of candidates were on one-member slates. $^{21}$

\footnotetext{
${ }^{18} \mathrm{As}$ in the regional elections, a slate must get at least $5 \%$ of all votes (including the preferential votes) to enter into the municipal council seat determination rule.

${ }^{19}$ In the analysis of municipal election data we also exclude the city of Olomouc (of 100 thousand residents) for the same reason.

${ }^{20}$ The use of middle names is extremely rare in the Czech Republic.

${ }^{21}$ These candidates will thus be effectively excluded from our regression analysis where we condition on
} 
We count the number of seats won by each slate and denote as 'electable' those candidates who are sorted high enough to be within this number. (Some slates thus have no 'electable' positions.) If there were no preferential votes (which can alter the implications of candidates' order within a slate), then holding an 'electable' position on a slate would be a perfect predictor of winning council seats. If there were no preferential votes and parties (slate coalitions) had perfect foresight as to their election success, the choice of who is positioned within the 'electable' subset of the slate would be all that mattered to candidates and parties. Excluding the one-candidate slates, about $27 \%$ of candidates were positioned high enough on their slates to be 'electable' according to this definition. Holding such slate positions was indeed important for getting elected as only $17 \%$ of council seats were won-thanks to preferential votes - by candidates positioned below the 'electable' part of their slate.

Next, we employ data from regional elections held in October 2008 when turnout was 40.3\%. Outside of the city of Prague, a total of 8,264 candidates on 192 slates participated in these elections for 675 seats on 13 regional councils with an average of 15 competing slates per regional ballot. Slates were ordered within ballots according to a national random draw of all participating nominating parties and coalitions. It so happened that one of the parliamentary parties, the Communist party, which nominated slates in all regions, was assigned the number 1 . It is therefore impossible to separately identify the effect of being first and the effect of being the Communist party in regional elections. ${ }^{22}$

Almost $70 \%$ of the slates did not win any regional legislature seats. There were over 2 million preferential votes cast for individual candidates. The lowest position on a slate winning a seat (thanks to preferential votes) was 50 (out of the maximum of 65). However, overall, given the regional election rules, preferential votes had little impact on winning seats in regional elections once the order of candidates on the slate is taken into account as less

\footnotetext{
slate fixed effects.

${ }^{22} \mathrm{http}$ ://www.mvcr.cz/clanek/statni-volebni-komise-vylosovala-cisla-pro-oznaceni-hlasovacich-listkupolitickych-stran-hnuti-a-koalic.aspx
} 
Table 1: Candidate Characteristics and Election Aggregates

\begin{tabular}{|c|c|c|c|}
\hline Elections & Regional & Large Municipality & Small Municipality \\
\hline Avg. age & 46.79 & 46.18 & 44.7 \\
\hline$\%$ Women & 29.33 & 32.57 & 30.95 \\
\hline$\%$ Full Professors & 0.19 & 0.10 & 0.01 \\
\hline$\%$ Associate Professors & 0.32 & 0.18 & 0.05 \\
\hline \% Ph.D. & 2.23 & 1.59 & 0.50 \\
\hline$\% \mathrm{MA}$ & 35.62 & 28.57 & 15.45 \\
\hline$\% \mathrm{BA}$ & 2.82 & 3.47 & 2.22 \\
\hline$\%$ with Law degree & 1.26 & 0.74 & 0.29 \\
\hline$\%$ with Medical degree & 4.38 & 3.03 & 0.76 \\
\hline $\mathrm{N}$ of councils (contests) & 13 & 321 & 5,786 \\
\hline $\mathrm{N}$ of slates & 192 & 2,766 & 24,417 \\
\hline $\mathrm{N}$ of candidates & 8,264 & 62,637 & 147,342 \\
\hline$\%$ of candidates winning seats & 8.17 & 11.97 & 34.93 \\
\hline Avg. \% share on slate's preferential votes & 0.023 & 0.044 & 0.166 \\
\hline
\end{tabular}

Notes: Data corresponding to 2008 regional and 2010 municipal Czech elections. Large municipalities have over five thousand inhabitants.

than $2 \%$ of seats were won by candidates outside of the 'electable' positions.

Table 1 summarizes the number of contests (councils), competing slates, and candidates, and compares means of candidates' demographic characteristics from the 2008 regional elections and the 2010 municipality elections separately for small and large municipalities. Our data cover thirteen regions, over three hundred cities with at least five thousand inhabitants, and almost six thousand small municipalities. As one would expect, the chances of a candidate winning a council seat and the number of competing slates per contest are both much lower in regional elections with districts of about one million inhabitants than they are in large cities, and they are the highest in small municipalities where over one third of candidates wins council seats. Similarly, shorter slates in small municipalities imply that the average across candidates of the candidates' share of their slate's preferential votes is highest in small municipalities at over sixteen percent. We note that the share of candidates winning a seat corresponds to the share of candidates positioned within a slate on what we denote as 
an 'electable' position.

Average age does not differ significantly across the three election contests we study and the share of women is also similar at about 30 percent. It is not surprising to see the share of candidates with academic titles of full or associate professor to be highest in regional elections and smallest in small-municipality contests. Similarly for graduate degrees: About a third of the candidates running in regional elections hold an M.A. degree while the corresponding share in small municipalities is about half that level. The share of candidates with either a law or a medical degree is particularly small in small municipalities.

Motivated by the discussion presented in Section 2, we have further coded a number of name characteristics. First, we have created an indicator (separately for each gender) of a candidate holding one of the five most popular first names in the country. ${ }^{23}$ Almost 30 (20) percent of male (female) candidates hold one of the five most popular first names. We have also coded indicators for candidates holding a typical Roma first or last name. ${ }^{24}$ Less than 1 percent of candidates hold such names. Second, in order to test whether linguistic characteristic of names that have been identified as potentially influential for consumer choices in the brand name literature may affect voter behavior, we have coded two indicators separately for first and last names: one for the presence of vowel repetitions, ${ }^{25}$ the other, 'initial plosive',

\footnotetext{
${ }^{23} \mathrm{We}$ used the five most frequent first names in the population name registry: http://www.mvcr.cz/clanek/cetnost-jmen-a-prijmeni-722752.aspx. Jana, Hana, Eva, Lenka, Martina for women. Jan, Jiří (George), Martin, Pavel, Petr for men. We have also added the first name Václav to the list of popular first male names based on the argument that the name is highly visible among the country's leading politicians including the first post-communist President Václav Havel or the long-serving Prime Minister Václav Klaus.

${ }^{24}$ We use five first names (Demeter, Fero, Dezo, Imrich, and Istvan), similar to the number of popular first names, and a longer set of last names (Kovac, Horvath, Balaz, Lakatos, Balog, Kolompar, Sarkozi, Gerza, Olah, Demeter, Sivak, Ziga, and Nemeth). The selection is based in large part on Marek (2012).

${ }^{25}$ See, e.g., Argo et al. (2010) for work on cognitive effects of sound repetitions.
} 
indicating that the name starts with a plosive. ${ }^{26}$ Third, we use several controls for one's position within a slate. In our regression specifications we control not only for whether a given candidate is positioned within the ex-post 'electable' part of the slate, but we also condition on the (reverse) percentile position of candidates on a slate (such that higher values of this indicator correspond to a candidate being sorted high). In addition, we generate indicators to ask about the potential effect of a male candidate being sorted immediately above or immediately below a female candidate and we also assign to each first and last name its percentile position in the alphabetical order, ${ }^{27}$ which enables us to ask whether alphabetical sorting affects candidate order in election setting where parties determine the slate order, i.e., when candidates are not formally ordered based on the alphabet.

Finally, for each slate we also know whether it is registered under one of the national-level parties and we define indicators (fixed effects) corresponding to the identity of all registered parties and slate coalitions. ${ }^{28}$

\section{Results}

\subsection{Candidate-Level Analysis}

In this section, we study the effects of several types of candidates' characteristics, listed explicitly or implicitly on the ballot paper, for (a) the order of candidates on slates, (b) preferential votes received by candidates, and, ultimately, (c) getting elected. Specifically,

\footnotetext{
${ }^{26}$ Plosives are 'b', 'c', 'd', 'g', 'k', 'p', 'q', or 't' (Vanden Bergh et al., 1987; Lowrey et al., 2003).

${ }^{27}$ The percentile position is determined relative to the distribution of initials in the entire pool of candidates we study. The correlation of the shares of first-name as well as last-name initials on all candidates with the shares of name initials in the population register is 0.99 .

${ }^{28}$ Among the 60 parties and slate coallitions registered for the 2008 regional elections, there were seven parties that were in the central government coalitions either in 2008 or 2010: the Cristian Democrats (KDUCSL), the Social Democrats (CSSD), the Civic Democrats (ODS), the Communists (KSCM), the Green party (SZ), the Public Affairs party (VV), and the TOP09 party.
} 
the three outcome variables we attempt to explain using ballot information are (a) a binary indicator of whether a candidate is positioned high-enough on his or her slate to be 'electable', i.e., within the ex-post number of council seats won by a given slate, ${ }^{29}$ (b) a candidate's share (i.e., ranging from 0 to 1 ) on the sum of preferential votes cast for all candidates on his or her slate, and (c) a binary indicator of whether a candidate won a council seat.

We focus on the effects of age, gender, academic titles and graduate degrees, and of linguistic and other properties of names as cues, and we study several position/order effects as well. Since local slate political preferences are unobservable and potentially correlated with candidate average characteristics across slates, we focus on within-slate comparisons, i.e., we condition on slate fixed effects. We thus do not analyze which slates are ultimately more successful, but ask, for instance, whether ballot cues have predictive power for preferential votes cast by voters for a particular candidate, conditional on the overall attractiveness of that candidate's slate.

In both specifications of type (b) and (c), we condition on candidates' position on slates, i.e., on holding an 'electable' slate position, which is the focus of specifications of type (a). In doing so, we decompose the (within-slate part of the) ultimate election outcome into its two sources: the party-determined slate order and the voter-determined preferential votes. In specifications (a) and (b) we ask how ballot characteristics including name cues affect the choices of parties when ordering candidates on slates and the choices of voters when marking their preferred candidates within slates. Regression specifications (c) then 'translate' the effects of ballot-listed characteristics on preferential votes studied in specifications of type (b) into those relating to the ultimate election outcomes - winning seats.

Table 2 presents coefficients from OLS regressions ${ }^{30}$ of type (a), (b), and (c) estimated

\footnotetext{
${ }^{29}$ See Section 4 for the definitino of 'electable' slate positions. We have also estimated alternative specifications with the candidate percentile order within a slate serving as the dependent variable. The results, which are higly similar to those presented here, are available upon request.

${ }^{30}$ OLS is widely used in this literature (by, e.g., Kelley and McAllister, 1984; Matson and Fine, 2006; or
} 


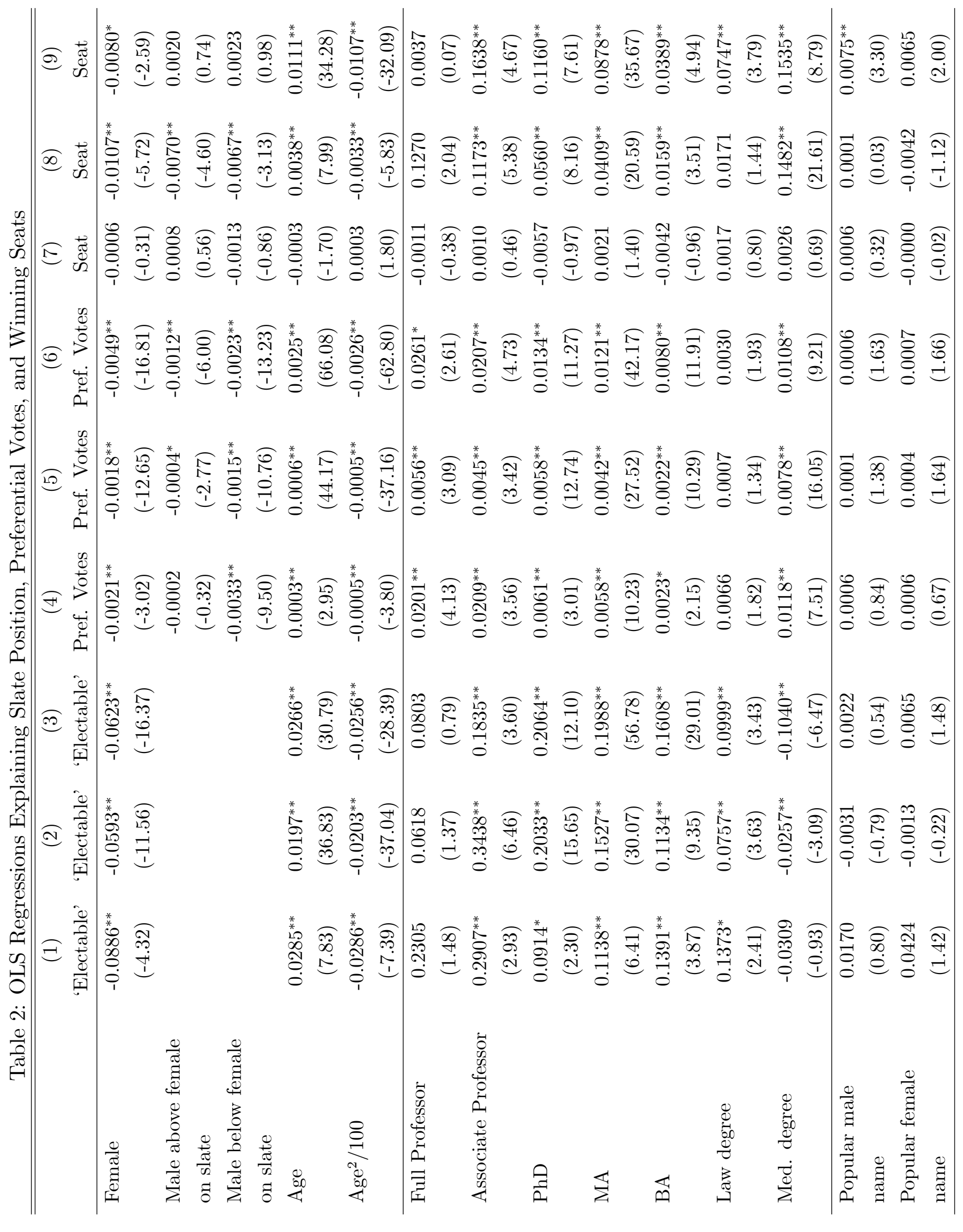




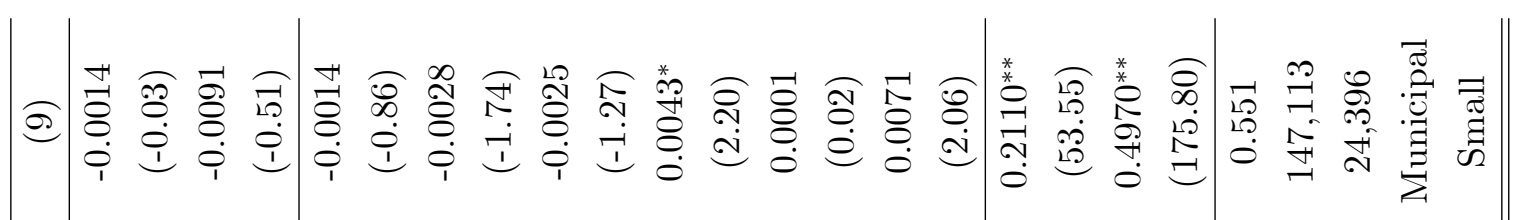

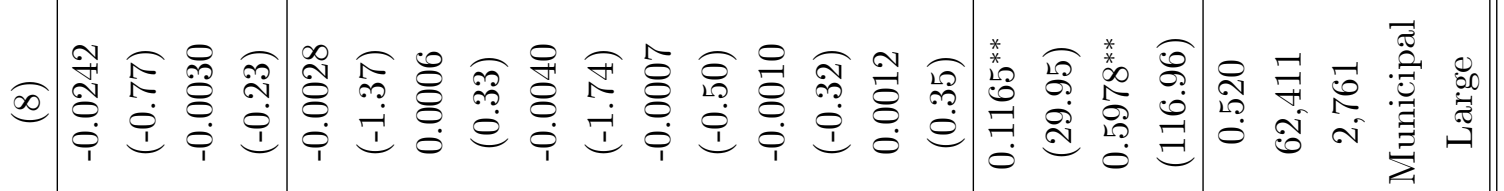

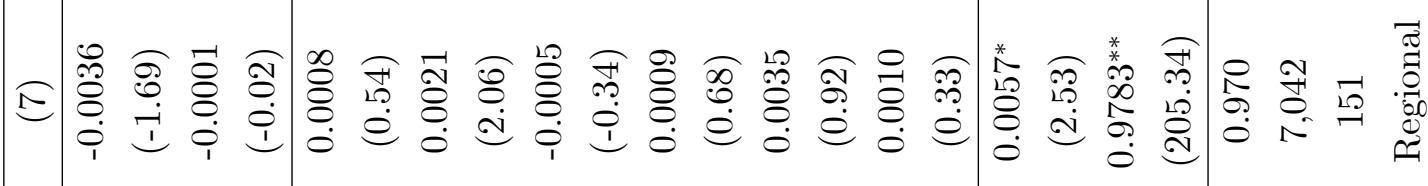

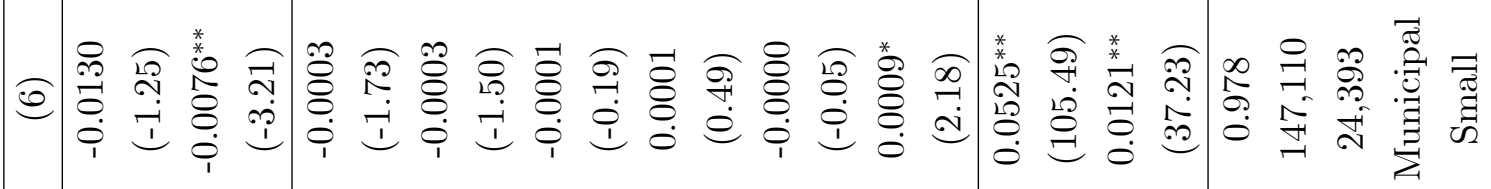

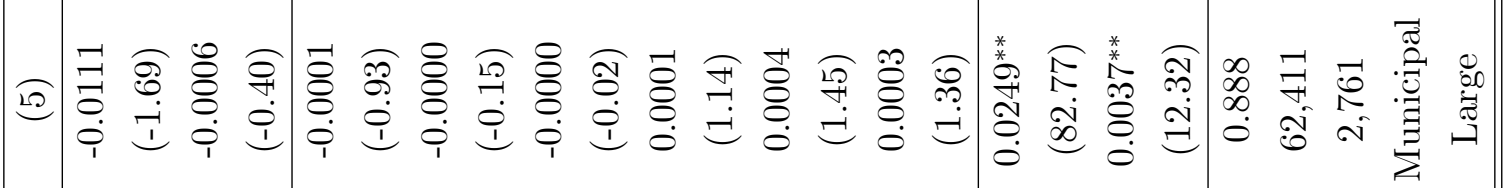

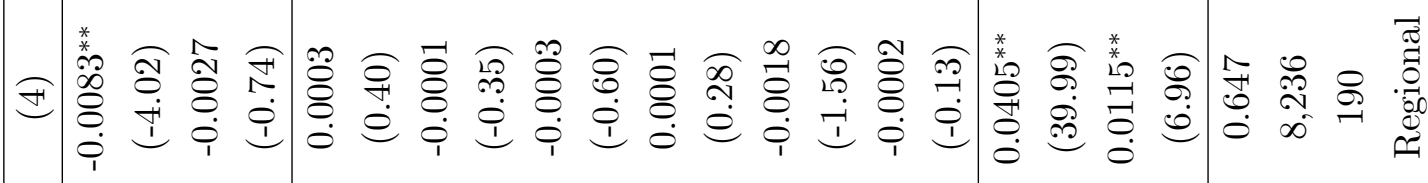

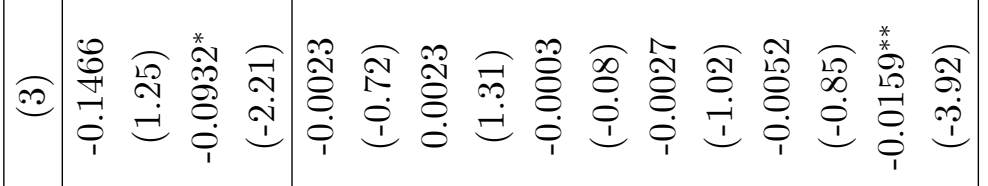

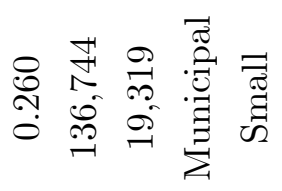

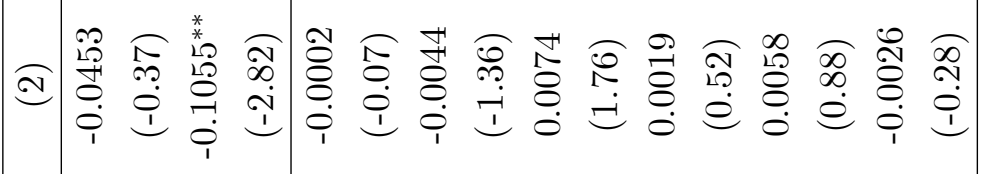

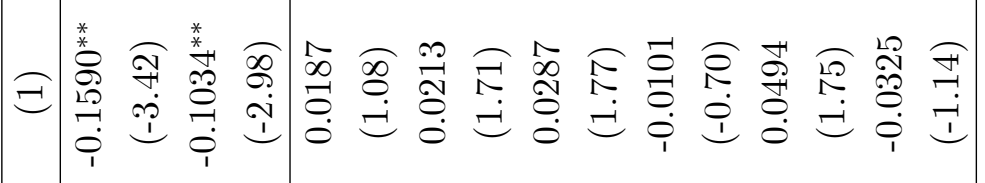

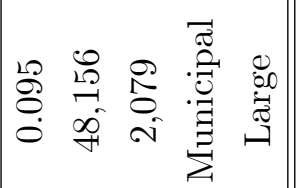

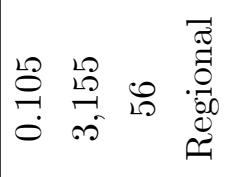

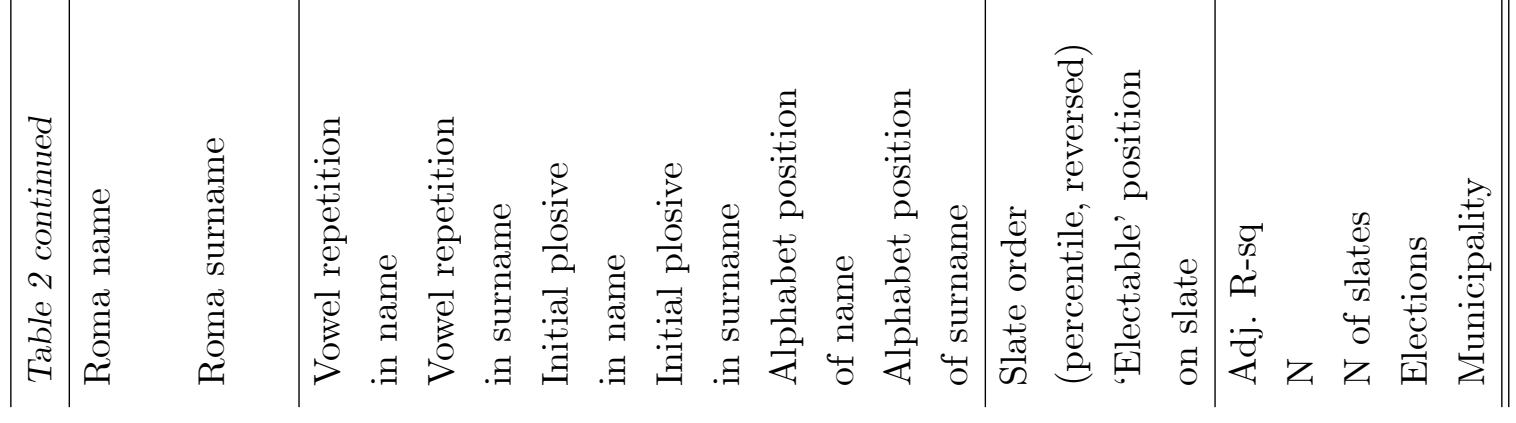

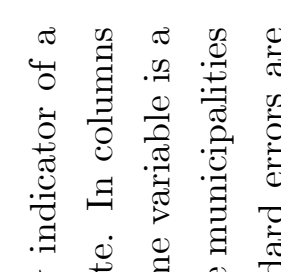
密

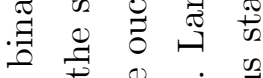
\%

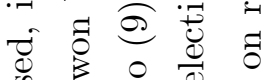

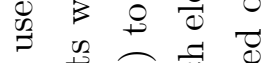

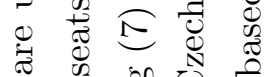

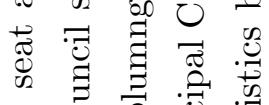

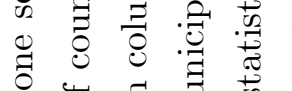
㟧

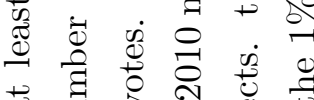

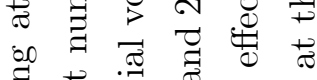

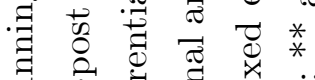

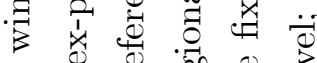
पै $\frac{\pi}{n} \equiv \infty$ क

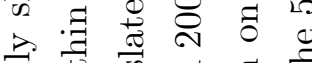

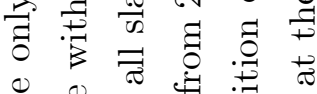

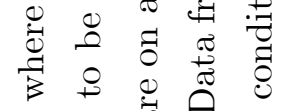

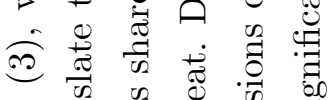
$\circ$ o d Є

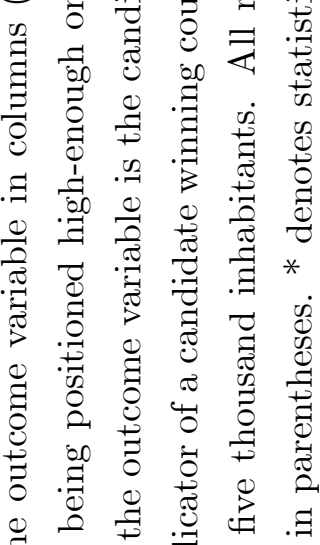
F

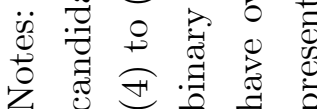


separately for the three election-contest groups presented in Table 1. ${ }^{31}$ More specifically, columns (1) to (3) of Table 2 present parameter estimates from regressions of a binary indicator of holding an 'electable' slate position on candidate characteristics in elections for regional legislatures and for councils of large and small municipalities. The question asked in the three regressions is what determines the probability that a candidate will be positioned high enough to stand a high chance of winning a council seat. As this question only applies to slates that won at least some seats, we estimate the regression on the subset of such slates. However, results are fully robust to including the slates that won no seats.

As attested by the first row of the table, women stand a substantially lower chance of holding 'electable' slate positions relative to men on the same slate with comparable ballotlisted characteristics: the probability is six to nine percentage points lower for women in the three-election setting we study. We also uncover positive, but diminishing 'returns' to age in terms of the chances of holding an 'electable' position on a slate with candidates in their fifties most likely to be 'electably' positioned. Next, it is clear that having an academic title or a graduate degree adds to one's chances of being sorted high on slates. The estimated effects are broadly comparable across the three election contests we distinguish and imply that being an Associate Professor is "worth" more in terms of helping one to be sorted high on a slate than having a graduate degree, which in turn helps one at least as much as having an undergraduate degree. Interestingly, lawyers secure higher positions than other graduate-degree holders while medical doctors do not.

Having a popular first name has a positive, quantitatively important, but statistically insignificant effect in regional elections, ${ }^{32}$ and appears not to affect slate order in munici-

Esteve-Volart and Bagues, 2012). We have compared the probability derivatives from a Logit model to the OLS coefficients and they were fully consistent; these results are available upon request.

${ }^{31}$ The number of candidates and slates used in these regressions is occasionally somewhat smaller than that presented in Table 1 due to minor shares of observations with missing values.

${ }^{32} \mathrm{~A}$ positive effect of having a popular name is consistent with two underlying mechanisms: parties may 
pality elections. In contrast, having a typical Roma first or last name has large negative effects across the board. Turning attention to linguistic properties of names, there are again quantitatively important, but statistically marginal positive effects of vowel repetition in the last name and of initial plosives in the first name in regional elections, consistent with the brand-name research cited above, but no discernible effect in municipality elections where candidate salience is likely higher.

There is only one statistically significant effect of the alphabetical position of one's name: ${ }^{33}$ in small municipalities, having a last name starting with 'Z' as opposed to 'A' lowers one's chances of holding an 'electable' position on a slate by about 1.5 percentage points (relative to the $35 \%$ average share of such candidates). This estimate is consistent with the notion that initial drafts of slates use alphabetically sorted lists and that 'hand-made' order changes in small municipalities are not sufficient to fully eliminate the initial sorting. Consistent with the presence of this suggested mechanism, one would expect no effects of first name initial alphabetical position. With the one exception of the coefficient corresponding to regional elections, which is only marginally significant, our expectations were confirmed in that the other eight estimated coefficients in Table 2 were precisely estimated zeros.

We also note that the explanatory power (adjusted R-squared) of ballot-listed characteristics for candidates' order on a slate is over twice as high in small municipalities where a higher share of candidates holds 'electable' slate positions and where candidate salience is likely to be higher. This could be explained by the lower availability of candidates with academic titles and graduate degrees in small municipalities leading to a higher 'election value' of such characteristics.

Next, columns (4) to (6) present the core of our analysis of voter behavior in lowexpect voters to generally prefer such names, or, given the high share of voters having such names, to vote for candidates who have the same name as the voter (as in Cutler, 2010, or Knewtson and, 2010).

${ }^{33}$ The explanatory variable is coded as one's percentile position in an alphabetically sorted list of all candidates in our data. 
information settings. Voters do not award preferential votes to women as generously as to male candidates comparable in terms of slate position and ballot-listed characteristics, but the difference is small at less than a half of a percentage point. A male sorted close to a female, particularly below a female, is less likely to receive preferential votes (conditional on his overall position on the slate captured by the 'electable' dummy and by the percentile slate order, which are both included in the regression). These effects, while interesting, are quantitatively very small.

Voters prefer higher academic titles and graduate degrees. Compared to candidates with other graduate degrees, medical doctors, but not lawyers, receive a higher share of the preferential vote awarded to all candidates on a given slate. Slate order set by parties is thus in contrast to voter preferences in terms of both the male-female and the doctor-lawyer comparison. Name properties including popularity or linguistic features have no effect on voter choices. $^{34}$ The exception is that typical Roma names again have a negative impact, which is similar in size to the positive treatment that medical doctors receive.

Slate position, captured by the 'electable' dummy and by a continuous measure of one's position in the slate list, has a major effect on the award of preferential votes in all three settings. Moving from the bottom to the top of the slate increases one's share of the slate's total of preferential votes received by as much as six percentage points - a large effect.

How do our estimates line up across the three election settings in view of the suggested differences in voter interest in and familiarity with the candidates? The importance of demographic, education, and ethnic correlates of candidate qualifications and political views (i.e., the importance of ballot information of type (ii)) appears to be similar in regional and small-municipality elections, despite the general agreement in the Czech political science literature that candidate salience is substantially higher in small municipalities. However, the explanatory power of all ballot-listed information for the award (within slates) of preferential

\footnotetext{
${ }^{34}$ The one statistically significant coefficinet (for last name alphabetical order in column (6)) is a precisely estimated zero.
} 
votes is highest in smaller election districts as the R-squared is close to $100 \%$ in municipal elections. Once local unobservable preferences for entire slates are filtered out of the data, slate order together with ballot-listed characteristics predict almost all of voter behavior in smaller election districts, even though candidate salience is likely to be high there.

This finding may correspond to voters relying on ballot information more heavily in smaller election districts because they actually do not differentiate between candidates based on personal knowledge or it could be the result of candidate true qualifications (unobservable to us) being more closely correlated with their observable ballot information in smaller districts. Unfortunately, given that ballot cues of type (iii) (i.e., name properties) are not predictive of voter behavior in all three settings, we do not provide much evidence on our hypothesis that heuristics and cues are more important in regional elections due to lower salience. ${ }^{35}$ We believe, however, that such comparisons, i.e., of the import of type (iii) information across elections, can in future be used to complement qualitative work on salience across election settings.

Finally, in columns (7) to (9) of Table 2 we measure the importance (magnitude) of the estimated differences in preferential vote driven by ballot-listed candidate characteristics in columns (4) to (6) for candidates' chances of actually winning a council seat. We do so by regressing a binary indicator of winning a seat on the same set of explanatory variables that were used in columns (4) to (6), i.e., including variables capturing one's position on a slate. We must quickly note that the election rules discussed in Section 3 imply that preferential votes have a negligible impact on regional election outcomes as less than $2 \%$ of regional legislature seats were won by candidates outside of the 'electable' slate positions. Hence, the only relevant coefficient in column (7) is the 'electable' dummy, which is close to 1 in

\footnotetext{
${ }^{35}$ Our only evidence of higher importance of name cues in regional elections comes from the marginally significant effects of initial plosives and vowel repetition on slate order and thus operates through party decisions, not voter decisions. In absence of an effect of these name properties on preferential votes, it is hard to argue that parties reflect these name properties in expectation of being rewarded for doing so by voters.
} 
value and which is chiefly responsible for the near-full R-squared of this regression. The only informative coefficients are thus found in columns (8) and (9).

Accounting for the disadvantaged slate position of women, they are about one percentage point less likely to win seats than male candidates comparable in terms of ballot information. Even being sorted close to a female candidate hurts the chances of male candidates in municipal elections in cities. Academic titles and graduate degrees have stronger positive effects in small municipalities than in large ones, with the exception of the equally-sized effect of holding a medical degree. Popular first names help male candidates win seats in small municipalities. Finally, linguistic properties of names have only negligible effects. Perhaps the properties we coded based on the English-language brand-name literature, even if we attempted to focus on general ones, are not applicable to the Slavic Czech setting.

\subsection{Slate-Level Analysis}

In Section 2, we discussed existing work that measures the election advantage to a candidate of being randomly sorted first on a ballot in single-seat elections. In multi-seat elections where candidates are organized by party slates, there could be a similar advantage to an entire slate being randomly sorted first on the ballot. In Czech regional and municipal elections, the ballot paper is often physically large and contains several slates and hundreds of individual candidates. ${ }^{36}$ It could be that the attention of voters to individual candidates or entire slates fades with the increasing amount of candidate information they are expected to process. We therefore use the random slate order to (be the first to) quantify the potential position advantage of the random slate order on ballots.

Slate order was randomized in both the regional and the municipal elections we study.

\footnotetext{
${ }^{36}$ For an example of a municipal ballot with nine slates and almost 250 candidates from the city of Náchod of twenty thousand inhabitants, see

http://upload.wikimedia.org/wikipedia/commons/3/37/Voting_ballot_Czech_communal_election_2010__district_N\%C3\%A1chod.pdf
} 
The randomization was conducted locally in each municipal election district, but nationally for all parties (slate coalitions) participating in regional elections. In municipal elections, we thus ask about the effect of being listed as the first slate and also about the effect of being among the first three slates on a ballot. Unfortunately, we cannot identify the effect of being sorted first in regional elections as the Communist party, which was randomly assigned the first position at the national level, nominated slates in all regions. It is therefore impossible to disentangle the part of the Communists' election outcome that reflects the political preferences of the electorate from the part that may correspond to the fact that they were always listed first on regional ballots and may therefore have received more attention. We can, however, ask about the effect of a slate being sorted second or third on a ballot in regional elections since not all of the sixty parties and slate coalitions that entered the national-level random draw of slate order numbers nominated slates in all regions. In particular, within the first twenty numbers drawn, there were only three national-level parties and seventeen mostly region-specific political entities, which did not nominate slates in most regions. ${ }^{37}$

Another issue with the comparability of estimates across the two elections we study concerns the typical number of competing slates in electoral competitions, which is an important factor for the question of whether slates sorted high on the ballot paper enjoy some attention advantage. The minimum number of competing slates in regional elections was thirteen, but most municipal election districts had less than ten competing slates. Since being randomly sorted within the first three slates cannot have a significant attention advantage when the total number of slates is small, we perform the analysis only for those municipal-election contests with at least thirteen competing slates; this way we also maximize the comparability of the estimated parameters across the two elections. ${ }^{38}$

\footnotetext{
${ }^{37}$ The national-level parties that drew low slate order numbers were Communists with number 1 , Cristian Democrats with number 12, and Greens with number 18. While the Communists are thus always first, the Cristian Democrats and the Greens are among the first three slates $80 \%$ and $30 \%$ of the time, respectively.

${ }^{38}$ We have further dropped from the municipal-election analysis all parties and coallitions that nominated
} 
Table 3: OLS Regressions Explaining Slate Electoral Success (Winning Seats)

\begin{tabular}{|c|c|c|c|c|c|c|}
\hline & (1) & $(2)$ & $(3)$ & (4) & $(5)$ & (6) \\
\hline \multirow[t]{2}{*}{ First } & - & $0.043^{*}$ & 0.001 & - & $0.018^{* *}$ & 0.004 \\
\hline & & $(0.024)$ & $(0.004)$ & & $(0.008)$ & $(0.003)$ \\
\hline \multirow[t]{2}{*}{ Second or Third } & $0.021^{*}$ & 0.014 & 0.004 & $0.022^{*}$ & 0.005 & 0.004 \\
\hline & $(0.012)$ & $(0.011)$ & $(0.003)$ & $(0.012)$ & $(0.006)$ & $(0.002)$ \\
\hline N (of slates) & 192 & 351 & 3,729 & 192 & 1,180 & 7,312 \\
\hline Min. N per district & 13 & 13 & 13 & 13 & 10 & 10 \\
\hline Party Fixed Effects & YES & YES & YES & YES & YES & YES \\
\hline Slate characteristics & - & - & - & YES & - & - \\
\hline Adj. R-sq & 0.94 & 0.55 & 0.01 & 0.95 & 0.49 & 0.06 \\
\hline Elections & Regional & Municipal & Municipal & Regional & Municipal & Municipal \\
\hline Municipality & - & Large & Small & - & Large & Small \\
\hline \multicolumn{7}{|c|}{$\begin{array}{l}\text { Notes: The outcome variable is the share of the council seats won by a slate. The explanatory } \\
\text { variables consist of indicators for a slate being sorted first on ballot paper and for being sorted } \\
\text { second or third. Slate characteristics are average candidate characteristics (from Table 2). Spec- } \\
\text { ifications listed in columns (5) and (6) additionally control for the number of slates competing }\end{array}$} \\
\hline
\end{tabular}

Table 3 lists regression parameters based on running the share of the council seats won by a slate on indicators for that slate being sorted first or for being sorted second or third. The outcome variable has a mean (standard deviation) of 0.24 (0.26) in small municipal election districts, 0.12 (0.11) in large municipal election districts, and 0.07 (0.13) in regional election districts. In column (1), we regress shares on regional legislatures won by each of the 192 slates participating in regional elections on a full set of sixty fixed effects (for all of the nationally registered parties and slate coalitions) and on an indicator of a slate being randomly listed second or third. The coefficient estimate implies that being sorted high on a ballot paper increases the share of seats won by a slate by about 0.15 of standard deviationa major effect. The effect of being listed first on a ballot in large-municipality contests in column (2) is twice as large. However, we find no significant effects of random slate order in only one slate. Given the inclusion of party fixed effects, these observations would not be used in any case. 
small municipalities, consistent with higher salience levels there.

In columns (4) to (6), we perform two types of robustness checks. First, we ask whether estimates are sensitive to controlling for average attractiveness of slates in terms of (slate averages of) various demographic and educational characteristics of candidates that we studied in the previous section. This specification issue is often discussed in the analysis of field randomized experiments. Controlling for characteristics (of control and treatment group participants) has little theoretical justification in large randomized trials where they are orthogonal to treatment (i.e., balanced across treatment status) by construction of the experiment. In small-sized experiments, however, one considers adding explanatory variables with the trade-off of increasing efficiency versus potentially introducing small-sample biases through over-controlling (e.g., Duflo et al., 2008). In our thirteen regional elections with 192 slates competing overall, only 26 slates can be second or third based on the random order and our 'treatment' group is thus rather small. Hence we compare regional-election estimates based on specifications controlling for slate characteristics in column (4) with those in column (1) that do not control for variables other than the random order, and find them identical. $^{39}$

Second, we consider whether the municipal-election findings are sensitive to the sample cut-off in terms of the minimal number of slates per competition. In columns (5) and (6), we extend the analysis to districts that had at least 10 slates competing for voters' attention. The estimated effect of being listed first in large-municipality contests is smaller, which is consistent with the notion that order attention effects are larger when there are more slates to process, and the results are qualitatively fully similar to those presented in columns (2) and $(3) .{ }^{40}$

\footnotetext{
${ }^{39} \mathrm{~A}$ similar comparison was performed for municipal elections with the same result.

${ }^{40}$ Specifications listed in columns (5) and (6) condition on one additional variable: As the share of seats won by a typical slate clearly declines with the number of competing slates in a district, we also control for the number of slates per district. The inclusion of this variable has only a small effect on the key estimates.
} 


\section{Conclusions}

How important are ballot-listed candidate characteristics for candidate order on slates, preferential votes, and election outcomes? We answer this question in three election settings that are likely to be ordered in terms of candidate salience whilst taking as given, by conditioning on slate fixed effects, both the endogenous choices involved in the formation of slates and the slate-specific local voter preferences.

We find that in Czech regional and municipal elections women tend to be nominated on poorer (lower) slate positions despite receiving almost identical preferential-vote support as comparable men. These findings are similar to estimates uncovered by Esteve-Volart and Bagues (2012) for Spain and De Paola et al. (2010) for Italy, respectively. In Czech regional elections where slate order is key to winning seats, the gender gap in the probability of holding an 'electable' slate position is almost nine percentage points. Even being sorted on a slate next to a female candidate lowers the chances of being elected for male candidates.

Academic titles and graduate degrees are strongly predictive of slate order and, conditional on slate order, have large positive effects on preferential votes and on the chances of winning council seats, especially in small municipalities where there are relatively few highly educated candidates. Voters also prefer doctors to lawyers even if parties do not.

The explanatory power of ballot-listed characteristics such as education for within-slate voter decisions is high, especially in smaller election districts. This finding could be interpreted as corresponding to uninformed voters using ballot-listed observables to guess about candidate quality. Alternatively, it could be that in small municipalities candidate ballotobservable characteristics are closely correlated, within slates, with their voter-observed quality, which remains unobservable to us. In order to fully disentangle the competing interpretations, future work should combine election data of the type we use with direct measures of

Further, it is not important whether we parametrize the effect of this additional control variable as linear or as a non-parametric step function in the number of slates. 
voter interest and knowledge of candidate quality.

One could also shed light on this issue by measuring the explanatory power for voter behavior of ballot cues that are uncorrelated with candidates' true qualifications and political views. Unfortunately, we are unable to provide a strong comparison across our three election settings in terms of the importance of such ballot cues. Name popularity and ethnic connotations do predict election behavior, but with few exceptions, we find linguistic properties of names to be of little importance. We do find ballot cues to play a role in small municipalities, despite the general agreement on high candidate salience there, but, overall, our estimates of ballot cue importance are weak and not systematically different across elections setting. While we therefore do not complement the qualitative evidence from Czech electoral studies suggesting that salience levels are high in small municipalities and voter interest low in regional elections, we do believe that the novel types of comparisons we provide could be fruitfully used in future research comparing election behavior across settings that are characterized by different levels of voter interest in and familiarity with the competing candidates.

Our second contribution to the literature on ballot effects is that we use randomized slate order to uncover a slate position advantage within ballots similar to that estimated for individual candidates when their order is randomized on ballots in single-seat elections. Specifically, slates ordered within the first three positions on ballot paper enjoy higher shares of council seats won in both regional and large-municipality election contests. These effects are quantitatively large at about 0.2 of a standard deviation. However, we find no sizeable effects of slate order in small municipalities, consistent with higher salience levels there. 


\section{Bibliography}

Argo, Jennifer J., Popa, Monica, and Malcolm C. Smith (2010) "The Sound of Brands," Journal of Marketing, 74: 97-109.

Aura, S., \& Hess, G.D. (2010). "What's in a name?" Economic Inquiry, 48(1): 214-227.

Balík, Stanislav (2009). Komunální politika: Obce, aktéŕi a cíle mistní politiky [Local politics: Municipalities, Drivers and Goals]. Prague, Grada Publishing.

Bernard, Josef (2012). "Individuální charakteristiky kandidátů ve volbách do zastupitelstev obcí a jejich vliv na volební výsledky" [The Personal Characteristics of Candidates in Municipal Elections and Their Effect on Election Results], Sociologicky casopis - Czech Sociological Review, 48(4): 613-640.

Bertrand, M., and Mullainathan, S. (2004) "Are Emily and Greg more employable than Lakisha and Jamal? A field experiment on labor market discrimination," American Economic Review, 94 (4): 991-1013.

Brockington, David (2003) "A low information theory of ballot position effect," Political Behavior, 25 (1): 1-27.

Cortese, Michael J. (1998) "Revisiting Serial Position Effects in Reading," Journal of Memory and Language, 29: 652-684.

Cutler, Fred (2002). "The Simplest Shortcut of All: Sociodemographic Characteristics and Electoral Choice," The Journal of Politics, 64 (2): 466-490.

Čmejrek, Jaroslav, Bubeníček, Václav, and Jan Čopík (2010) Demokracie v lokálním politickém prostoru [Democracy in the local political space]. Prague, Grada Publishing.

De Paola, Maria, Scoppa, Vincenzo, and Lombardo, Rosetta (2010) "Can gender quotas break down negative stereotypes? Evidence from changes in electoral rules," Journal of Public Economics, 94 (5-6): 344-353.

Duflo, Esther, Glennerster, Rachel, and Michael Kremer (2007) "Chapter 61: Using Randomization in Development Economics Research: A Toolkit," In: T. Paul Schultz and John A. Strauss, Editors, Handbook of Development Economics, 4: 3895-3962. 
The Economist (2001) "As easy as ZYX," 360(8237): 13.

Esteve-Volart, Berta, and Bagues, Manuel (2012) "Are women pawns in the political game? Evidence from elections to the Spanish Senate," Journal of Public Economics, 96(3-4): 387-399.

Faas,Thorsten, and Harald Schoen (2006) "The importance of being first: Effects of candidates' list positions in the 2003 Bavarian state election," Electoral Studies, 25: 91-102.

Fujiwara, Thomas (2013) "Voting Technology, Political Responsiveness, and Infant Health: Evidence from Brazil," mimeo, Princeton University.

Havlík, V., and L. Hoskovec (2009) "Krajské volby v České republice v kontextu konceptu voleb druhého řádu. Analýza vybraných aspektů voleb do krajských zastupitelstev v letech 2000-2008" [Regional Election in the Czech Republic in the Context of SecondOrder Elections: Analyzsis of Selected Aspects of Regional Elections during 2000-2008], European Electoral Studies [Evropská volební studia], 4 (1): 22-47.

Jurajda, Š., and Münich, D. (2010) "Admission to Selective Schools, Alphabetically" Economics of Education Review, 29 (6): 1100-1109.

Kahneman, D. (1973) Attention and effort. Prentice-Hall Inc.

Kelley, Jonathan, and McAllister, Ian (1984) "Ballot paper cues and the vote in Australia and Britain: alphabetical voting, sex, and title," Public Opinion Quarterly, 48: 452466.

Knewtson, Heather S., and Richard W. Sias (2010) "Why Susie owns Starbucks: The name letter effect in security selection," Journal of Business Research, 63: 1324-1327.

Lowrey, Tina M., Shrum, L. J., and Dubitsky, Tony M. (2003) "The Relation Between Brand-name Linguistic Characteristics and Brand-name Memory," Journal of Advertising, 32 (3): 7-17.

Lowrey, Tina M., and Shrum, L. J. (2007) "Phonetic symbolism and brand name preference," Journal of Consumer Research, 34 (3): 406-414. 
Marek, Tomáš (2012) “Je Jiř́i Dvořák lépe zaměstnantelný než Demeter Lakatoš?” [Is Jiří Dvořák more employable than Demeter Lakatoš?] Prague School of Economics, mimeo.

Matson, Marsha, and Fine, Terri Susan (2006) "Gender, Ethnicity, and Ballot Information: Ballot Cues in Low-Information Elections," State Politics $\&$ Policy Quarterly, 6 (1): 49-72.

Meredith, Marc, and Salant, Yuval (2013) "On the Causes and Consequences of Ballot Order Effects," Political Behavior, 35(1): 175-197.

Nelson, Leif, D., and Simmons Joseph, P. (2007) "Moniker Maladies: When Names Sabotage Success," Psychological Science, 18 (12): 1106-1112.

Schneider, Sebastian, and Tepe, Markus (2011) "Dr. Right and Dr. Wrong: zum Einfluss des Doktortitels auf den Wahlerfolg von Direktkandidaten bei der Bundestagswahl 2009" [Dr. Right and Dr. Wrong: The Impact of a PhD Title on the Electoral Success of Direct Candidates in the German Federal Election 2009] Politische Vierteljahresschrift, $52(2): 248-285$.

Smith, G. (2007) "The influence of name sounds in the Congressional elections of 2006," Names, 55 (4): 465-472.

Šaradín, P. (2008) Teorie voleb druhého řádu a možnosti jejich aplikace v České republice [The Second-Order Election Theory and the Possibilities of its Application in the Czech Republic]. Olomouc, Univerzita Palackého.

Yorkston, Eric., and Menon, Geeta (2004) "A Sound Idea: Phonetic Effects of Brand Names on Consumer Judgments," Journal of Consumer Research, 31: 43-51.

van Ours, J., \& Ginsburgh, V.A. (2003) "Expert opinion and compensation: evidence from a musical competition," American Economic Review, 93(1): 289-296.

van Praag, M., \& van Praag, B.M.S. (2008) "The benefits of being economics professor A (rather than Z)," Economica, 75: 782-796.

Vanden Bergh, Bruce G., Adler, Keith, and Lauren Olivier (1987) "Linguistic Distinction Among Top Brand Names," Journal of Advertising Research, 27(5): 39-44. 


\section{Working Paper Series}

ISSN 1211-3298

Registration No. (Ministry of Culture): E 19443

Individual researchers, as well as the on-line and printed versions of the CERGE-EI Working Papers (including their dissemination) were supported from institutional support RVO 67985998 from Economics Institute of the ASCR, v. v. i.

Specific research support and/or other grants the researchers/publications benefited from are acknowledged at the beginning of the Paper.

(c) Štěpán Jurajda and Daniel Münich, 2014

All rights reserved. No part of this publication may be reproduced, stored in a retrieval system or transmitted in any form or by any means, electronic, mechanical or photocopying, recording, or otherwise without the prior permission of the publisher.

Published by

Charles University in Prague, Center for Economic Research and Graduate Education (CERGE) and

Economics Institute of the ASCR, v. v. i. (EI)

CERGE-El, Politických vězňů 7, 11121 Prague 1, tel.: +420 224005 153, Czech Republic.

Printed by CERGE-EI, Prague

Subscription: CERGE-EI homepage: http://www.cerge-ei.cz

Phone: + 420224005153

Email: office@cerge-ei.cz

Web: http://www.cerge-ei.cz

Editor: Marek Kapička

The paper is available online at http://www.cerge-ei.cz/publications/working_papers/.

ISBN 978-80-7343-304-8 (Univerzita Karlova. Centrum pro ekonomický výzkum a doktorské studium)

ISBN 978-80-7344-297-2 (Akademie věd České republiky. Národohospodářský ústav) 
CERGE-EI

P.O.BOX 882

Politických vězňů 7

11121 Praha 1

Czech Republic http://www.cerge-ei.cz 